\title{
Revisionist Spectacle? Theatrical Remediation in Alejandro G. Iñárritu's Birdman and Quentin Tarantino's The Hateful Eight
}

\author{
Sarah E. Beyvers \& Florian Zitzelsberger
}

For one to whom the real world becomes real images, mere images are transformed into real beings - tangible figments which are the efficient motor of trancelike behavior. (Debord $§ 18$ )

Theater performances seem to have lost their hegemonic importance for collective experience and forfeited the influence they once exerted on cultural productions. This is hardly surprising because within a "cultural economy [that] privileges the mediatized and marginalizes the live," as Philip Auslander asserts, theater and cinema are "rivals, not partners" (Liveness 46, 1). ${ }^{1}$ Whereas the distinctiveness of theatrical performance lies in its ephemerality, the cinematic experience is reproducible and thus more likely to enter the economic realm, contributing to the autopoiesis ${ }^{2}$ of cinema which subsequently validates itself as an eligible form of entertainment. However, theater has undergone a process of repopularization 'for the masses' in recent years, a development that entails mediatization, as for example the Royal National Theatre's popular project National Theatre Live illustrates. Yet, as will be elucidated in the following, several performance scholars agree that the act of immortalizing liveness bereaves theater of its political power. Guy Debord's Marxist theory of the spectacle and its perpetual selfvalidation subscribes to the notion that mass phenomena are simply incapable of passing on criticism, let alone reflecting on their status in society, and on their integration in the capitalistic market. What happens, therefore, if cinematic film reverses this process by emulating theatrical performance? This article argues that the remediation of theater in film - that is the incorporation of feigned theatrical signs like one-shot scenes, static camera angles, and the use of diegetic ${ }^{3}$ music in motion

pictures - infuses the spectacle with the political power more frequently attributed to 


\section{IJCS}

live performance. As semiotic transitions that are not narratively motivated, instances of theatricality in film dissipate diegetic illusion, draw attention to the constructedness of film, similar to alienation effects in Brechtian theater, and comment on the relationship between cinema and the medium it remediates, theater.

Following an explanation of how film can remediate theatrical performance on the basis of their similar semiotic constitution, this article specifically looks at filmic genres that do not provide a justification of theatricality. Using Quentin Tarantino's The Hateful Eight (2015) and Alejandro G. Iñárritu's Birdman or (The Unexpected Virtue of Ignorance) (2014) as examples, we illustrate how both films foreground audiences' expectations towards seemingly formulaic genres that are frequently and readily perceived as uncritical products of the entertainment industry, and comment on both their commercial framing and on cinema's status as a mass phenomenon in a society progressively dependent on mediatization. As Ludwig Feuerbach postulated in 1843 in the preface to the second edition of The Essence of Christianity, modernity "prefers the sign to the thing signified, the copy to the original, fancy to reality, the appearance to the essence" (Feuerbach XIII) and that is why "[a]ll that once was directly lived has become mere representation" (Debord §1), a spectacle, reaffirming existing power structures and market forces.

\section{REMEDIATING THEATER IN FILM}

Taking into account the fact that the origins of cinematic films are aligned with the tradition of theatrical performance, and that in its early stages, film certainly "continued to create an impression of immediacy and presence" (Belton 4), the difference between theater and film is not just a question of mediatization. ${ }^{4}$ Rather, we need to focus on the ways in which (the impression of) immediacy is generated and how information is framed in both media. From a semiotic perspective, it can be asserted that theater and film share many of the same signs that constitute and convey meaning. In his book, The Field of Drama, Martin Esslin canvasses the sign systems that drama, which he uses as an umbrella term for both film and theater, employs in its "re-enactment of 'real' or fictional events" (28). He places emphasis on the idea that theater and film have more in common than what sets them apart. Indeed, the sign systems that first come to mind when thinking about film, such as the actor, movement within the frame, verbal and non-verbal signs, music as well as visuals and design, ${ }^{5}$ can also be found in theater. These signs, no matter whether they occur in theater or film, facilitate the creation of an illusion on stage and screen; the spectator hence concludes a contract with the "performative situation that establishes that it has to be taken as a sign" (Eco 117), endorsing the viewer's "suspension of disbelief" (115). Precisely because theater and film are representational media, their meaning-making strategies do not differ significantly, even though both may use signs to compensate for those of the other medium they cannot reproduce. Both stage and screen endow new meanings through the interplay of signs within their respective frames, metonymically linking their representations to the corresponding points of reference.

However, as Noël Carroll points out, "each artform has its own distinctive medium that distinguishes it from other forms. [T] he medium qua essence dictates 
what is suitable to do with the medium" (49-50; original emphasis). This argumentation already hints at the medium-specific properties of film: Although film is not necessarily different from theater in most of its basic semiotic constitution, it will most likely employ additional signs. The signs film uses are, once the production process is closed, static in a sense that filmic material does not change; the genesis of meaning depends on the reception of said material. In theater, contrastingly, signs can vary in the very instance of reception due to the synchronicity of production and reception. In other words, the additional signs film creates identify the medial artefact in question as a film because they are usually nowhere to be found in theater. Above all, as a result of its inherent stasis, film can be characterized by selectivity. Whereas in theater the spectator assembles individual visual impressions, the cinematic gaze is predetermined by the camera and the combination of shots through editing (Esslin 97).

Zeroing in on film and its adoption of theatricality, which Bolter and Grusin would classify as an instance of "remediation" (45; original emphasis), ${ }^{6}$ it becomes evident that the presence of theatrical signs and the relative absence or, rather, covertness of specific filmic signs is prevalent in some genres. The film musical, for example, excessively draws on theatricality; especially the backstage musical, which is about putting on a show, remediates theatrical performance very blatantly because acting, singing, and dancing "have a solid justification as necessary activities in this particular world" (Belton 148), making theatricality indispensable for the genre. Drawing attention to the fact that film remediates theater as one of its predecessors through the overt employment of theatricality undeniably constitutes a self-reflexive engagement with film as medium and theater as the artform which informs it. However, in the case of the backstage musical, this self-reflexivity is naturalized or narratively motivated and thus does not impede the audience's immersion. Even though such films emulate the theatrical experience to a certain degree by means of remediation, the quality of theatricality in film is different from the elements which can be found in theater; the signs in film are not perceived immediately but in a mediatized fashion through the projection onto a screen. Especially since the second half of the twentieth century, and even more so since the turn of the millennium, "popular film is becoming progressively more hypermediated" (Bolter and Grusin 154). The increasing employment of digital editing techniques leaves audiences accustomed to mediatization and digitalization, and is, subsequently, perceived as an essential part of the cinematic format.

\section{GENRE AND ALIENATION EFFECTS IN FILM}

Conceiving of remediation and mediatization as meaning-making strategies inherent to the medium film, the use of theatricality can take away cinema's distinctive voice and heighten the viewers' critical awareness. However, one cannot disregard the ways in which specific genres of film influence the degree of explicit filminess; extending Carroll's assertion of media-specificity, it becomes clear that, even though the medium and its semiosis are at stake, the generic formations within the medium predetermine which signs or sign systems are actualized or more strongly pronounced 


\section{IJCS}

in a film. If genre, according to Rick Altman, functions as "blueprint," "structure," "label," and "contract" (14; original emphasis), then specific signs, by convention, become genre markers and make it possible for the audience to identify a genre as such. For example, films like The Hateful Eight are recognized as westerns because of their distinct use of settings, music, and props that evoke the myth of the American West (Belton 244). Of course, these choices are made during the production process of the films; nonetheless, they play a vital role in terms of distribution and marketing, as well as in terms of reception. As Altman argues, "the interpretation of generic films depends directly on the audience's generic expectations" (14). That is to say, because genre represents a contract between the producer, the artefact, and the consumer, conventions and expectations as to what constitutes a genre influence our impression and interpretation of the film - generic codes prescribe how the signs used in film have to be deciphered. That is also why films such as Birdman, although set in a theater, thus seemingly naturalizing the employment of theatricality within its diegesis, ${ }^{7}$ are not met with the same expectations as film musicals, for example. Because of its framing, starting with the title, its leading actor, the film's trailers and posters, Birdman will most likely be identified as a superhero/action film, which enables the film to play with the audience's expectations by transgressing genre conventions.

As argued above, the integration of theatrical elements in film, not in the sense of those elements theater and film share but, rather, those that signal theatricality and liveness, can be seen as a self-reflexive engagement with the medium film and its relationship with theater as the remediated source. Some filmic genres, like the film musical, provide narrative motivation for the adoption of theatricality, and thus do not necessarily realize the potential of their inherent self-reflexivity as a means to dissipate diegetic illusion. On the contrary, theatrical elements make up a fundamental portion of the appeal and immersive power of these films. If theatricality is not naturalized within the genre, however, as is the case with The Hateful Eight and Birdman, whose genres do not thrive on the blatant use of theatrical signs, instances of theatricality distort filmic illusion and impede the audience's immersion. Similar to Brechtian theater, which uses signs usually ascribed to narrative media to detain the audience from identifying with and immersing itself in the represented world (Brecht 91), it can be asserted that theatrical elements in film create a similar effect by reversing the process. Following Brecht, we call theatrical elements in film that are not narratively motivated alienation effects, the English equivalent to Brecht's Verfremdungseffekte. While such effects in theater are "designed to destroy theatrical illusion[,] and promote in the audience a critical attitude towards what is happening on stage" ("Verfremdungseffekt" 864), filmic alienation effects draw attention to the mediumspecific properties of film. As Brecht asserts, alienation effects function as a distancing technique; the investment in and negotiation of what is represented on stage and on screen shifts from the viewers' subconscious to a conscious plane (91). If filmic illusion is broken, the film's narration, and with it the framing devices of cinematic film, come to the fore. In that respect, alienation effects facilitate a critical engagement with the "'framedness' of all perception, cognition and reception" (Wolf 28), the medial nature of film and its specific generic conventions, expectations of audiences, 
and the status of film in the (mass) media landscape. In other words, film can incorporate theatrical signs, but the employment of these exposes that film is precisely not what it at times feigns to be- theatrical performance. ${ }^{8}$

\section{THE POLITICS OF THEATER AND SPECTACLE}

This distinction between film and theatrical performance - the fact that film's mediatized images cannot compensate for the ephemeral nature of live theater lost in the very process of remediation - elicits a necessary discussion of the (a)politicality of both art forms: Phelan argues that "[p]erformance clogs the smooth machinery of reproductive representation necessary to the circulation of capital"-precisely because it cannot be recorded, performance "eludes regulation and control [...] [, and] resists the balanced circulations of finance" (148). ${ }^{9}$ Following this reasoning, in juxtaposition to film, theater could be regarded as anticapitalistic and (at least) less commercialized, because live performance cannot be replicated. If theatrical performance is filmed, however, the resulting product enters the cultural marketplace and is subsequently subject to the forces of capitalism and censorship, and thus to the industry's politics. Therefore, mediatization brings with it commercialization as well as the filtering processes of camera angles, positions, settings, and cuts. This development can be observed in the live broadcasting and recording of live performances by the projects National Theatre Live and Metropolitan Opera Live in $H D$ : When the Royal National Theatre, for example, broadcast Benedict Cumberbatch's performance in Hamlet, it reached 225,000 people in 25 countries at once (Hawkes). The success of such live broadcasts to the silver screen contributes to the re-popularization of theater 'for the masses' as well as to its mediatized commercialization. Bearing Phelan's argument in mind, this process would block theater's political potential and impede the spectators' critical awareness.

Similarly, Guy Debord perceives mass phenomena such as Hollywood cinema as uncritical products of The Society of the Spectacle, which lends its name to his seminal study. He criticizes spectacles and argues that "the spectacle is both the outcome and the goal of the dominant mode of production [...] [, ] epitomiz[ing] the prevailing model of social life [...] [and] serv[ing] as total justification for the conditions and aims of the existing system" (§6). If film remediates theater, theatrical elements conform to cinema as a mass phenomenon and are no longer untainted by the mechanisms of capitalism. On the one hand, this makes the theatrical experience available to a larger audience. On the other hand, theatrical performance loses its immediacy and, thus, its political power. The spectacle is "capital accumulated to the point where it becomes image" (\$34) which can be observed in the spectacular marketplace of, for example, Hollywood, where the production processes as well as the distribution of filmic material are strongly regulated and aim at the creation of films that appeal to the masses. Above all, the purpose of the spectacle is to generate money, and money is a prerequisite for the genesis of new spectacles. As a consequence, "critical awareness [has] ceased to be" (\$25) because the spectacle only ever celebrates itself. This is consistent with Phelan's argumentation of theater's 


\section{IJCS}

politicality, because, following Debord, the spectacles of a mediatized culture are only able to - and merely strive to - develop into themselves (§14); their "means and [...] ends are identical" (\$13) and they are therefore expected to be simply unable to "think outside the (spectacular) box.'

To recapitulate, because its ephemerality cannot be recorded, live performance in theater can be considered as a medium capable of passing on criticism and thus as having a political dimension. The spectacle, in contrast, eludes this kind of criticism due to its mediatization and integration in a capitalistic market. What, then, happens if spectacles (try to) emulate live performance and make use of signs traditionally associated with theater? Although theater and film share most of their basal sign systems, remediation changes the quality of these signs and how they are perceived. Through the cinematic filter, theatrical signs are mediatized and specific filmic elements are added. In that respect, remediation itself implies a statement on the relationship between the two media. Acts of incorporating illusions of liveness and other theatrical elements into film draw attention to the constructedness of film and its very existence as a mediatized spectacle as opposed to immediate live performance. This self-reflexivity, however, has to be seen in the context of the respective film's genre. In contrast to narratively motivated and naturalized instances of theatricality, the films under consideration in this article, Birdman and The Hateful Eight, belong to genres whose aesthetics usually do not comprise theatricality. That is why, as will be shown in the following, theatricality has an alienating function that breaks diegetic illusion and, in clear distinction to Debord's assertion, enables these cinematic spectacles to engage critically with aspects of their own mediality, questioning notions of media specificity. Furthermore, semiotic transitions as the result of the remediation of theater provoke genre transgressions because the theatrical signs used in these films are not naturalized, which challenges the very notion of genre and accentuates the political implications of spectacleness and theatricality in relation to genre.

\section{“THE NAME OF THE GAME HERE IS PATIENCE."-THEATRICALITY IN THE HATEFUL EIGHT}

Looking back at The Hateful Eight's framing, nothing about the publicity of Quentin Tarantino's eighth film is surprising at first glance. The initial trailer, for example, urged audiences to anticipate a Tarantinoesque celebration of violence, suspense, and action ("Official Teaser Trailer"). However, there was one novelty about the film which was bound to excite cinephiles around the globe: As the trailer announced, the motion picture had been filmed in "glorious 70mm (Ultra Panavision 70)" ("Official Teaser Trailer"), "an arcane camera process last used in the Fifties and Sixties on horizon-stretching extravaganzas like Ben-Hur and The Fall of the Roman Empire" (Collin). Yet, when it came to the film itself, the special camera technique was only used for a handful of landscape shots - since the film is, for the most part, set in one single room. This fact drove a wedge between reviewers and moviegoers alike. In comparison to Tarantino's previous two films, Inglourious Basterds (2009) and Django Unchained (2012), The Hateful Eight fared relatively badly at the box office and grossed 'only' \$155,760,117 worldwide ("The Hateful Eight"), 350 per cent 
of its budget ${ }^{10}$ several critics chided the film for its spatial constriction and slow pacing, calling it "Tarantino's worst film [...] [,] a sluggish, unimaginative dud" (Gleiberman), "lacking in character and narrative coherence," or simply "gosh-darn boring" (Clarke). However, other reviewers recognized and praised the film for what it aspires to be - a chamber drama (e.g. Robbins, Bradshaw, Collin).

The Hateful Eight's development history is symptomatic of its ubiquitous theatricality: After the script leaked online in January 2014, Tarantino considered publishing it as a novel instead (Fleming). But after a live reading of the script with his favored cast in front of sixteen hundred people on a theater stage, the filmmaker changed his mind and decided to film The Hateful Eight anyway (Mitchell vi). This conveys perfectly what makes Tarantino's eighth film different from his previous works: The Hateful Eight's script could be easily performed on stage without any major changes. The film has been called "stubbornly theatrical" and "the first Tarantino movie that might be called a drama" (Vishnevetsky).

The film makes such excessive use of theater codes that the far-flung instances of explicit 'filminess' seem to shatter the theatrical illusion and forcibly remind the viewers that they are in a movie theater - not a theater. The Hateful Eight is mostly set in (or sometimes in front of) two different 'rooms,' a stagecoach and Minnie's Haberdashery. The limited space does not only stand for The Hateful Eight's 'stageability,' it is also a meta-commentary on the stage as a representation, and imitation, of the real world (Aristotle 3; 10). Even though Tim Roth's character Oswaldo Mobray suggests, after disagreements between Confederate and Unionist veterans, that they do not "restage the battle of Baton Rouge during a blizzard in Minnie's Haberdashery" (01:04:45), that is exactly what they do. To prevent further dispute, Minnie's is divided into North and South (the dinner table serves as a neutral zone), and the 'stage' therefore becomes "America writ small, fraught with all the hideous, baked-in racial tension [...], an entire nation in a single room" (Collin). Looking more closely, it stands out that Tarantino's film meticulously adheres to the classical unities of a tragedy, which had been seen as a necessity for the audience's immersion for a long time: The Hateful Eight follows only one plot (unity of action), it is limited to a time period of 24 hours (unity of time), both of which were proposed in Aristotle's Poetics (13-15; 9). The film is also, for the most part, set in the single room of Minnie's Haberdashery, which suggests unity of place, a category that cannot be ascribed to Aristotle, but was added later. Another idiosyncrasy of classical tragedies can be found in the film's structure: Faithful to Tarantino's modus operandi, The Hateful Eight is divided into chapters. In his eighth film, however, this receives a connotation contrary to literariness. The film consists of six chapters, but presents itself rather as having five plus one chapters; the last section is not numbered like the previous ones - it is simply called "Final Chapter." Without the fifth part, which is a flashback of how the Haberdashery's real inhabitants died, The Hateful Eight's sectioning is redolent of a classical tragedy's five-act-structure.

The film's original absurdly wide screen ratio is not used to show far-stretching horizons, but rather the claustrophobic spaces of the overcrowded stagecoach and Minnie's. This hint at, yet lack of, visual decadence draws the viewers' attention to the 


\section{IJCS}

characters, their facial expressions and gestures, and most of all to the nuanced dialogue. The Hateful Eight's plot progression is completely dialogue-based - almost nothing ever happens and, since the film does not make use of many cinematic techniques depicting a character's thoughts, the viewer's only source of information is verbal exchange between the protagonists. The characters are drawn through speech rather than action and this can most definitely be described as a characteristic that, even though it may be used in film, originated in theater. The incorporation of theatricalized dialogue has become something of a trademark of Tarantino's: Django Unchained's dinner scene and Inglourious Basterds's opening scene, for example, feature characters who put on an act and pose as someone else or someone with different intentions. This is also the case in The Hateful Eight, since the only characters who appear as their true selves are John Ruth, Marquis Warren, Daisy Domergue, O.B. and (possibly) Chris Mannix; every other character plays a role. In the scenes mentioned above as well as in The Hateful Eight in its entirety, exits, entrances, and (dramatic) pauses receive major importance and the pacing is slowed to a point where it bears close resemblance to that of a traditional play. As John Ruth, the Hangman, aptly utters: "The name of the game here is patience" (02:13:21).

As shown above, The Hateful Eight thrives on the excessive use of theater codes. However, both the film's theatricality and the viewers' resulting immersion in the illusion of immediacy and liveness are broken by the almost aggressive use of filmic elements. At the level of cinematography and editing, the extreme long shots of the niveous landscape in the first scenes already seem to stress The Hateful Eight's filminess. However, since the movie's entire plot takes place inside or in front of the stagecoach and Minnie's, this is soon eclipsed by the theatrical experience it provides. Towards the end of the film, this illusion of theatricality is, in turn, shattered by the sudden introduction of slow motion during the shootout following the Mexican standoff (01:55:30; 02:25:30). Tarantino's work is so slow and quiet in its pacing and nuanced in the depiction of its protagonists that the last 30 minutes appear to be completely out of place: The impasse the eponymous eight characters find themselves in culminates in a violent debauchery, which, faithful to Tarantino's practice hitherto, savors the brutal death of character after character. The Hateful Eight's ending is, regarding the overabundance of blood and murderous frenzy, not in any way inferior to, for example, the bar and movie theater shootouts in Inglourious Basterds. These and other scenes of violent 'overkill' brim over with specific film codes, such as extreme slow motion, special effects or extradiegetic music: ${ }^{11}$ This metaphorically bursts the bubble of theatricality and feigned liveness and demonstratively reminds the viewers of the properties of the medium they are engaging with.

In addition to The Hateful Eight's excessive depiction of (filmic) violence, another aspect also assumes a very important role in the text's use of film codes as alienation effects. As the tension peaks and claims the first life, Quentin Tarantino's disembodied voice explains the following:

About fifteen minutes have passed since we last left our characters. Joe Gage volunteered to take Smithers' body outside. Straws were drawn to see who'd help him. O.B. lost. Chris, John Ruth and Oswaldo had a vigorous debate about the 
legality of the self-defence murder that just transpired. Major Marquis Warren who was supremely confident about the legality of what just transpired ignored them, sat at the table by himself and drank brandy. Captain Chris Mannix donned the dead General's coat and joined Oswaldo in lighting the candles and lanterns. [...] Domergue, however, hasn't moved from her spot at the community dinner table since John Ruth uncuffed her. [...] Let's go back a bit. [...] Fifteen minutes ago, Major Warren shot General Smithers in front of everybody. But about forty seconds before that, something equally as important happened, but not everybody saw it. While Major Warren was captivating the crowd with tales of black dicks and white mouths, somebody ... poisoned the coffee. And the only one to see him do it ... was Domergue. That's why this chapter is called 'Domergue's Got a Secret.' (01:32:39-01:35:01)

Tarantino's voiceover impedes the audience's full immersion because it draws attention to the film's constructedness. The filmmaker explains his motivations for calling the chapter in question "Domergue's Got a Secret," and this fourth wall break thus reminds the viewers of the film's 'unrealness' and enables them to take up an observer's position. This is, following Brecht, the central impact of alienation effects - an indispensable prerequisite for a critical and distanced engagement with the events on stage or screen.

Additionally, Tarantino's appearance as a literary narrator serves another purpose. The statement that the coffee was poisoned in front of all characters but "not everybody saw it" alludes both to the spectator's wandering gaze in theater and film and to the selectivity of a camera: If a character were to poison a pot of coffee on a theater stage, however inconspicuously, some members of the audience would be likely to have seen it. Summarizing Bert States, Coley argues as follows:

[O]ne of the central differences between the effects of film and theater is the different ways that the audience focuses, or is allowed to focus, on particular images [...]. The vantage point of the film viewer is within the perspective of the camera's lens, as determined by the film's director. The vantage point of the theatrical viewer is always in some way outside of any one perspective, with each audience member being able to choose his or her own focus and perspective. (Coley 16-17)

The Hateful Eight draws attention to the fact that it is, notwithstanding its mock theatricality, a film. The viewers are reminded (by the director, ironically) that they are at the mercy of the filmic filters of the camera, such as the editing process. The entirety of the audience is not able to see who poisoned the coffee, simply because this information does not appear in the final product. Hence, Tarantino's voiceover also serves as a meta-commentary on the mechanisms of manipulation and on the viewers' susceptibility to it in film as opposed to theater. 


\section{IJCS}

\section{"THIS IS THE THEATER, HONEY. DON'T BE SO SELF-CONSCIOUS."- RECIPROCAL ALIENATION AND METALEPSIS IN BIRDMAN}

Even though Birdman has been framed as an action film centered around the superhero Birdman throughout, it is as much a spectacle as it is a film about theater. Contrary to the impression passed on through its trailers and movie posters, Alejandro Iñárritu's film is not the average superhero movie but, rather, a backstage film. The film is about Riggan Thomson, the actor who played Birdman in the fictional Birdman series within the film, and follows the production of the play What We Talk About When We Talk About Love. ${ }^{12}$ The film can thus be segmented into the following narrative levels: ${ }^{13}$ The film's primary plotline, which follows the mounting of Riggan's play, is situated on the intradiegetic level, whereas both the play and the film within the film constitute narratives on a higher level, the metadiegetic. These levels are very much ontologically different in that the intradiegetic conveys a sense of realism and the metadiegetic is conceived as fictional within the diegesis. Within the metadiegetic level, the respective medial products, film and play, further differ in their semiotic quality. This already hints at what Birdman is really about: Live performance and its cinematic remediation. The following will focus on how Birdman makes use of narrative metalepses that dissolve the border between the intra- and metadiegetic levels,${ }^{14}$ how salient instances of theatricality and spectacleness function as alienation effects within the diegesis, and how this reflects on the film's genre and its status as a mass phenomenon in the media landscape.

While the fictional film Birdman is frequently talked about in Iñárritu's Birdman, it does not take center stage because the main act really is Riggan's play. During the rehearsals and the premiere of the play, both of which are situated on the metadiegetic level, instances of theatricality are naturalized within the diegesis; they are prerequisite for and consequence of the scenes in question. This does, however, not account for the excessive use of theatrical elements throughout the film because the intradiegetic level (the backstage storyline, so to speak) lacks narrative motivation for the employment of theatricality. For example, elements like extradiegetic music that are specifically denoted as filmic signs are exposed as paralogisms when the drum player who can already be heard during the film's opening credits suddenly appears on the street (00:31:20) or inside the theater building (01:36:13). The drums (as well as the drum player) are thus part of the mise-en-scène and by no means extradiegetic, even when they, at first glance, seem to be heard from 'offscreen.' Similarly, in another scene, the assumed extradiegetic music turns out to be the metadiegetic music of the play rehearsed on stage (00:40:45): while we expect the music to be a cinematic device for the linking of scenes or the creation of suspense, it purposely uncovers itself as a theatrical element. Birdman moreover heavily draws on theatricalized dialogue which is underlined by the characters' strong facial expressions, gestures, and voices. Riggan's daughter Sam and method actor Mike Shiner, in particular, represent two rather exaggerated characters. Mike almost appears as a caricature of the clichéd highbrow theater actor (e.g. 00:15:45), and Sam is emotionally unstable and rather impulsive (e.g. 00:37:48). Both frequently act as if they had to bridge the distance between a stage and an audience. The theatricalization of filmic elements can be 
understood as an alienation effect because it consciously neglects the audience's genre- and medium-specific expectations; it neither provides the cinematic experience that it was advertised to be, nor does it draw on signs that are specifically filmic. Rather, Birdman throws the viewer off track, and offers (the illusion of being) a live performance.

This is further elicited by one of the most compelling and innovative features of the film: For the most part, Birdman appears to be shot in one take. This is due to digital editing which establishes the impression of continuity, "bind[ing] the spectator within a cohesive cosmos" (Benson-Allott 10) without visible cuts. The emphasis here is on visibility (or the lack thereof), because the film conceals its digital enhancement by feigning the synchronicity of production and reception that is only found in live performance. This illusion of continuity is, however, in some instances broken by the paradoxical linkage of scenes that defy the rules of time and space. In one scene, Mike and Sam are kissing above the stage. The camera then tilts and reveals that Mike is part of the rehearsal on stage (01:06:55). Such instances blatantly point towards the film's mediatedness and to the fact that it is not a live performance. The twisted logic behind Birdman's effect of continuity becomes most apparent during its rehearsal scenes where the play and intradiegetic reality are not distinguishable anymore (e.g. 00:14:20). After realizing that Riggan switched his gin with water, for example, Mike utters: "I'm supposed to be drunk [...] you've fucked with the plot" (00:23:30). While Mike breaks the border between the metadiegetic (the play) and the intradiegetic levels, he does not really break character. Such instances of metalepsis blur the line between play and reality, and question whether the characters' motivations and behavior are real or just an act. In the same scene, Mike breaks the fourth wall by addressing the audience, who was taking pictures of his outburst: "Oh, come on, people. Don't be so pathetic. Stop looking at the world through your cell phone screens! Have a real experience! Does anybody give a shit about truth other than me?" (00:23:56). On the one hand, this is, again, a metalepsis that dissolves the border between the meta- and intradiegetic levels. On the other hand, the intradiegetic audience can metonymically be substituted with the audience of the film. In that respect, Mike's statement implies a comment on film as a medial representation and criticizes the audience for its passive consumerism. He urges the audience to not subscribe to the commodities of the spectacle but, rather, to engage critically with the medium, and reminds the viewers that liveness (the "real experience") cannot be remediated by film.

Although the previous remarks show that metalepses are often provoked by Birdman's illusion of continuity, this impression at the same time contributes to the immersion of the audience. Precisely because the viewer becomes accustomed to this mode of presentation rather quickly due to the film's ubiquitous use of theatricality, instances of explicit filminess seem to alienate the audience even more. Interestingly, Birdman's filminess is the result of metalepsis as well, and it is, just like instances of stark theatricality, framed as a self-reflexive element that invades the intradiegetic level: With the appearance of the character Birdman on the intradiegetic level, the semiotic qualities of the metadiegetic Birdman film and the intradiegetic level blend 


\section{IJCS}

into each other, and disrupt the theatrical illusion. For example, after Riggan shoots himself during the premiere of his play, the illusion of continuity is broken by a multitude of visible cuts (01:38:17-01:39:38), a technique only found in film. Towards the end of the film, when Riggan's alter ego, Birdman, is seen for the first time, the screen erupts into a cinematic spectacle of overwhelming action. After Riggan snaps his fingers, a fireball strikes a car, and helicopters, gunfire, explosions, and a gigantic mechanical bird dominate the scene. Birdman comments on this and addresses the viewers directly: "That's what I'm talking about! Bones rattling! Big, loud, fast! Look at these people, at their eyes - they're sparkling. They love this shit! They love blood. They love action. Not this talky, depressing philosophical bullshit!" (01:26:00). This break of the fourth wall almost aggressively draws attention to the fact that, while audiences are likely to expect an action film (such as the metadiegetic Birdman), Iñáritu's Birdman does not really offer a spectacular experience. In that respect, the film alludes to the audience's expectations of superhero films which, in turn, can be read as a negotiation of Birdman, whose genre does not meet these expectations. Moreover, as Werner Wolf argues, the "paradoxical 'impossibility' of metaleptic transgressions seems to lay bare the fictionality of the work in which they occur and thus implies a meta-statement on its medial nature as an artefact" (Wolf, "Metareference" 50). Birdman not only shows that genres are constructions based on conventions; it also raises questions about its mediality as a film.

Contrary to Sam's assertion (00:16:30), Birdman "is [not] the theater," and it is in fact very much "self-conscious." Through the employment of theatrical elements and exaggerated filmic elements as alienation effects, the film almost constantly refers to itself. It uses the resulting critical distance to engage in a self-reflexive discourse about theater (the medium whose liveness it feigns and which it includes in its plot) and film (the medium which it notwithstanding constitutes), art and mindless spectacle. According to Riggan, theater is not about labels but about technique, structure, and intention (01:20:20). In Birdman, artistic theater is the counterpart to capitalistic cinema, which Riggan turned his back on. The binary of theater/cinema strongly correlates with the dichotomies of high culture/low culture, actor/celebrity, prestige/popularity. Mike spells out the clear hierarchy Birdman offers regarding theater and cinema, claiming that "popularity is the slutty little cousin of prestige" (00:31:13). The positive evaluation of theater corresponds with the prevalence of classical theatrical elements in the film. On the one hand, Birdman does not celebrate itself as a spectacle but as theater on the levels of plot, characters, and design. On the other hand, Birdman, the embodied spirit of mass media, whose voice metaleptically appears in Riggan's dressing room, elucidates that (capitalistic) cinema considers itself above theater: "How did we end up here? This place is horrible. Smells like balls. We don't belong in this shithole" (00:02:00). These contradictory statements about the relationship between theater and film are symptomatic of Birdman in its entirety. While Birdman frequently focuses on the rivalry between theater actors like Mike Shiner and former movie star Riggan Thomson, the signs the film uses to convey this narrative are also involved in the constant fight to obtain the upper hand. However, the abundance of theatrical elements at the beginning of the film and the sudden 
dominance of filmic elements towards the end seems ironic or even nonsensical, because Birdman is, after all, a film.

As a film about theater, Birdman shows that "theatre might well add gravitas and credibility to a performer, but these days no one at all is anything unless mediated by the screen" (Brown). The only reason why Birdman attracted an audience is because it is a film with a commercial framing as an action film (as opposed to the drama it really is) and not a theatrical production confined to a single stage. It shows that our society depends on mediatization and that spectacles are designed to appeal to the masses. However, Birdman's self-reflexivity potentially prompts critical awareness in the audience; the reciprocal alienation of theatrical and filmic elements - the fact that the film does not provide a clear image of its genre affiliation and the perceived hierarchy between theater and film - serves the purpose of making the viewers think for themselves. Considering the dominating sign systems in relation to the audience's expectations, Birdman's alienation effects constitute a chiastic structure which "force[s] readers from one discipline to think about an issue in terms more appropriate to their counterparts in another discipline, and vice versa" (Ceccarelli 5; original emphasis). Truly consistent with Riggan's motto, which is shown several times in his mirror, "A thing is a thing and not what is said of that thing" (e.g. 00:03:07), Birdman's audience has to look behind the film's commercial framing and its spectacleness in order to see that, while the film creates an illusion of liveness, mediatization (and, by extension, spectacle) can imply illusion, estrangement, and, ultimately, falsehood.

\section{FILM AS SPECTACLE—THEATRICAL FILM AS REVISIONIST SPECTACLE}

While cinematic film can be considered a spectacle that aims at satisfying a broad spectatorship in order to gross money, the use of theatrical elements and the establishment of theatrical illusion in film challenges this notion. Even though the spectacle is invested in reiterative practices of perpetual self-validation, thus stabilizing and solidifying existing structures of an "economy of repetition" (Auslander Liveness 46), our analyses have demonstrated that theatrical films can emerge as revisionist spectacles. As representatives of genres whose semiosis usually spotlights filminess, The Hateful Eight and Birdman not only reimagine the genre conventions of the western and of superhero films but also the relationship between film and theater in times characterized, as Auslander advocates, by a "conflation of the cultural and the economic," which "renders "critical distance' impossible" ("Political" 59). ${ }^{15}$ Taking into account performance scholars such as Peggy Phelan, who claim that live performance's unreproducibility makes it independent of cultural market forces, mainstream cinema would need to be seen as incapable of reflecting on its own status as a product in the spectacular marketplace. However, as we have argued, feigned liveness and other theatrical elements in film render this selfreflexivity possible. Through their ubiquitous theatricality, yet unmistakable filminess, The Hateful Eight and Birdman both comment on the alleged impossibility of a spectacle's self-criticism from within as participants of the system of the mainstream film industry—as filmic fifth columnists, so to speak. ${ }^{16}$ 


\section{IJCS}

The Hateful Eight achieves this by establishing a façade of liveness and theatricality, which is subsequently broken by the conspicuous use of film codes. Furthermore, Tarantino's eighth film has been called his first political film in a long time:

If Tarantino's two previous films, Inglorious Basterds (2009) and Django Unchained (2012) offer visual counter-narratives to history (and to film history) through satisfying "what ifs" in which the good guys win, The Hateful Eight seeks more fundamentally to superimpose new images over old ones. In Tarantino's western, black faces and spaces are central to the American narrative, both outside and in. [...] Freighted with allusions to the damage that white men do, Tarantino's eighth film demands to be seen not as a revisionist but a newly visioned western, using the mythmaker's tools to offer a panoramic vision of racial sovereignty undone by random violence. (Robbins 369-70)

This is made possible through the employment of theater codes; the film crosses the 'boundaries' of its medium and enables a look behind the curtain of its own 'spectacleness' and commercialization.

Birdman makes use of narrative metalepses to engage in a self-reflexive discourse about the medial nature of theater and film, represented by Riggan's play and the fictional Birdman franchise within the film. The reciprocal alienation of filmic and theatrical elements further points towards the audience's expectations, which are prompted by the film's commercial framing, and the constructedness of genre labels. Its illusion of liveness may be used to emphasize the power of editing techniques. However, because this illusion is broken in various instances, the film comments on mediatedness as the essential constituent and coevally one of the major flaws of the cinematic spectacle because it can never fully remediate liveness.

As Bolter and Grusin argue, "[o]ur culture wants to both multiply its media and to erase all traces of mediation: ideally, it wants to erase its media in the very act of multiplying them" (5), which is exactly what Birdman and The Hateful Eight strive to do. Both films use filmic means (such as, for example, digital editing or special camera techniques) in order to create an illusion of liveness and a sense of immediacy. They heavily draw on theatrical signs and, at the same time, try to cache their spectacleness. Considering the films' genres (i.e. western and action film), it can be asserted that, because it is not a prerequisite for either genre, theatricality has an alienating function and foregrounds the audience's expectations towards the films' genres: Birdman and The Hateful Eight do not offer the same degree of spectacleness their commercial framings lead to assume. On the contrary, they deliberately transgress their genres' conventions and seemingly step outside of the comfort zone of the spectacle. That both films nonetheless blatantly exhibit their own mediatedness by breaking the theatrical illusion not only constitutes a comment on the impossibility of reproducing live performance but also a negotiation of the political power of theater and the alleged depoliticized status of cinema. The notion of filmic alienation effects has to be rephrased at this point to fit the ambiguous status of Birdman and The Hateful Eight as theatrical films whose illusion is reciprocally disrupted by the exuberance of signs 
that oppose the codes generating and constituting this illusion. The employment of alienation effects therefore enables Birdman and The Hateful Eight to foreground a critical attitude towards cinema without leaving its realm. Hence, the spectacle is able to comment on its own status and can operate politically within the confinements of its capitalistic system. However, this is sometimes interconnected with the danger of financial losses, as is the case with The Hateful Eight, if the film leaves the realm of the spectacle for the masses and becomes more than, to use the words of Karl Marx, ${ }^{17}$ 'opium of the people.' 


\section{IJCS}

\section{NOTES}

1. A brief remark on terminology: For the purposes of this article, mediatization is defined in contradistinction to liveness. While live performance is perceived immediately, mediatized performance, be it in a film or the live broadcast of a play, is regulated by some sort of filter, for example, the camera and (digital) editing. Accordingly, mediatization (as a process) and mediatedness (as a state) refer to the ways in which digital media frame meaning. In the case of film, this quality may also be referred to as filminess, since it identifies a film as such, whereas theatricality describes the qualities of theatrical performance that signal liveness. When discussing the adoption of theatricality in film, we therefore focus on the use of signs that usually constitute or are a result of theatrical production. Peggy Phelan assumes a rather purist position when claiming that live performance can never be "saved, recorded, documented, or otherwise participate in the circulation of representations of representations" (146). However, projects like National Theatre Live do record theatrical performance, thus making it repeatable. These recorded performances nonetheless differ from live performance in their quality. The implications of this development will be explained in more detail in the section on "Remediating Theater in Film."

2. Autopoiesis, according to Luhmann, whose system theory gained popularity in various academic fields, signifies the ability of a system to reproduce its structures by way of using its own systemic material (348).

3. Diegesis refers to the narrated world. It, therefore, needs to be set apart from the level of narration: Since theater mostly does not openly display a frame of narrative mediation, music is commonly presented as an occurrence within the textual world and is, in distinction to extradiegetic music in film, not added from without, for example through editing. Pfister, however, emphasizes that this 'absoluteness' of theater constitutes an illusion, which can subsequently be broken in instances wherein the intra- and extradiegetic communicative levels shortcircuit (22).

4. Coley, for example, draws on phenomenology and argues that theater and cinema, despite their differences in terms of mediatization, both make use of light in the creation of the cinematic/theatrical illusion (14).

5. For a detailed overview of the signs theater and film use to generate meaning and their semiotic symbiosis, see Esslin (43-105).

6. According to Bolter and Grusin, remediation is distinctive of digital media such as film, and the practice of remediation unveils the "perceived competition or rivalry between the new media and the old," the remediated (45).

7. Despite its setting, Birdman does not provide a justification of the employment of theatrical signs. While it makes sense to theatricalize some scenes such as rehearsals or the premiere of Riggan's play, the occurrence of theatrical elements in the film's backstage storyline, i.e. scenes that are not part of a theatrical performance, is not naturalized within Birdman's diegesis, and is thus perceived as a disruption of filmic illusion. 
8. This can also be seen in the context of theatrical illusion in film where decidedly filmic elements take on an alienating function obstructing the audience's immersion, which will be demonstrated in our case studies of The Hateful Eight and Birdman.

9. Auslander criticizes this approach and states that theater or live performance cannot but operate within the same cultural economy as mass media (Liveness 45).

10. To enable comparison, it shall be noted that Inglourious Basterds had a worldwide gross of $\$ 321,455,689$ ("Inglourious Basterds") which made up 460 per cent of its budget, whereas Django Unchained made \$425,368,238 ("Django Unchained"), 430 per cent of its budget.

11. Even though theater can also make use of, for example, extradiegetic music, The Hateful Eight frames its entry as a filmic element, since the extradiegetic score is exclusively used to accompany other decidedly filmic elements.

12. This reference to Raymond Carver's 1981 short story collection of the same name adds another layer to Birdman's interplay of fiction/reality by authenticating the backstage storyline on the intradiegetic level.

13. For a definition of narrative levels, see Genette (228); this notion has later been applied to film narratology (Kuhn 85).

14. For a definition of metalepsis as the transgression of the border between logically separate narrative or ontological levels, see Genette (234) and Wolf (50). We use the term in a broad sense, i.e. metalepsis does not only refer to characters crossing this threshold but to the interference of narrative levels with all of their semantic and semiotic features.

15. The argument brought forth here is in accordance with Guy Debord's theory of the spectacle.

16. We need not forget, however, that these films are nonetheless produced by the mainstream film industry. The questions that therefore arise are, on the one hand, who decides to incorporate theatrical elements in film and, on the other hand, whether these elements are really used to forge criticism or if they merely serve as window dressing to obscure the capitalist alignment of mainstream cinema. Additionally, as long as it is not broken, theatrical illusion contributes to the immersion of the audience. Even though the systems Birdman and The Hateful Eight emerge from still prevail, theatricality in film, as we argue, potentially prompts critical awareness in the viewer, ultimately ascribing the recognition of criticism to the act of reception.

17. The Society of the Spectacle in its entirety may be read as a paraphrase of Karl Marx, especially when Debord conceives of spectacles as "tangible figments which are the efficient motor of trancelike behavior" (\$18), an assertion which, true to the inherent reiterative and tautological nature of the spectacle, marks both the beginning and end points of our discussion. 


\section{IJCS}

\section{WORKS CITED}

Altman, Rick. Film/Genre. BFI Publishing, 1999.

Aristotle, and Malcolm Heath. Poetics. Penguin Books, 1996.

Auslander, Philip. Liveness: Performance in a Mediatized Culture. Routledge, 1999.

---. "Toward a Concept of the Political in Postmodern Theatre." From Acting to Performance: Essays in Modernism and Postmodernism. Routledge, 1997, pp. 5872.

Belton, John. American Cinema/American Culture. McGraw-Hill, 2013.

Benson-Allott, Caetlin. "Cinema's New Appendages." Film Quarterly, vol. 64, no. 4, 2011, pp. 10-11.

Birdman or (The Unexpected Virtue of Ignorance). Directed by Alejandro G. Iñárritu, $20^{\text {th }}$ Century Fox Home Entertainment, 2014.

Bolter, Jay D., and Richard Grusin. Remediation: Understanding New Media. MIT Press, 1999.

Bradshaw, Peter. "The Hateful Eight Review: Agatha Christie with Gags, Guns and Samuel L Jackson.” The Guardian, 19 Dec. 2015. Accessed 20 Mar. 2018.

Brecht, Bertolt. "Alienation Effects in Chinese Acting." Brecht on Theatre: The Development of an Aesthetic, edited by John Willett, Methuen, 1974, pp. 91-99.

Brown, William. "Birdman and the Intoxicating Alchemy of Cinema." The Conversation, 5 Jan. 2015. Accessed 20 Mar. 2018.

Carroll, Noël. Theorizing the Moving Image. Cambridge UP, 1996.

Ceccarelli, Leah. Shaping Science with Rhetoric: The Cases of Dobzhansky, Schrödinger, and Wilson. Chicago UP, 2001.

Clarke, Donald. "The Hateful Eight Review: The Wheels Come Off the Wagon." The Irish Times, 7 Jan. 2016. Accessed 20 Mar. 2018.

Coley, David. Projected Performances: The Phenomenology of Hybrid Theater. Louisiana State UP, 2012.

Collin, Robbie. "The Hateful Eight Review: 'Only Tarantino Can Do This'." The Telegraph, 7 Jan. 2016. Accessed 20 Mar. 2018.

Debord, Guy. The Society of the Spectacle. Translated by Donald Nicholson-Smith. Zone Books, 1995.

"Django Unchained." Box Office Mojo. Accessed 20 Mar. 2018.

Eco, Umberto. "Semiotics of Theatrical Performance." The Drama Review, vol. 21, no. 1, 1977, pp. 107-117.

Esslin, Martin. The Field of Drama: How the Signs of Drama Create Meaning on Stage and Screen. Methuen, 1987.

Feuerbach, Ludwig. The Essence of Christianity. Kegan Paul, Trench, Trübner \& Co., 1890.

Fleming, Mike Jr. "Quentin Tarantino Shelves 'The Hateful Eight' after Betrayal Results in Script Leak." Deadline Hollywood, 21 Jan. 2014. Accessed 20 Mar. 2018.

Genette, Gérard. Narrative Discourse. Basil Blackwell, 1980.

Gleiberman, Owen. "Film Review: Is The Hateful Eight Tarantino's Worst?" $B B C$ Culture, 18 Dec. 2015. Accessed 20 Mar. 2018.

The Hateful Eight. Directed by Quentin Tarantino, Universum Spielfilm, 2015.

"The Hateful Eight." Box Office Mojo. Accessed 20 Mar. 2018. 
"THE HATEFUL EIGHT - Official Teaser Trailer - The Weinstein Company." YouTube, 12 Aug. 2015. Accessed 20 Mar. 2018.

Hawkes, Rebecca. "Live broadcast of Benedict Cumberbatch's Hamlet watched by 225,000 people.” The Telegraph, 21th October 2015. Accessed 20 Mar. 2018.

"Inglourious Basterds." Box Office Mojo. Accessed 20 Mar. 2018.

Kuhn, Markus. Filmnarratologie: Ein erzähltheoretisches Analysemodell. Walter de Gruyter, 2013.

Luhmann, Niklas. Social Systems. Translated by John Bednarz. Stanford UP, 1995.

Mitchell, Elvis. Foreword. The Hateful Eight: A Screenplay, by Quentin Tarantino, Grand Central Publishing.

Pfister, Manfred. Das Drama. Wilhelm Fink, 2001

Phelan, Peggy. Unmarked: The Politics of Performance. Routledge, 1996.

Robbins, Hollis. "U.S. History in 70 MM: The Hateful Eight (2015). Directed by Quentin Tarantino." The Journal of the Gilded Age and Progressive Era, vol. 15, no. 3, 2016, pp. 368-370.

"Verfremdungseffekt." The Oxford Companion to the Theatre, 1983.

Vishnevetsky, Ignatiy. "Quentin Tarantino Gets Theatrical in the 70mm Western The Hateful Eight." The A.V. Club, 16 Dec. 2015. Accessed 20 Mar. 2018.

Wolf, Werner. "Metareference across Media: The Concept, Its Transmedial Potentials and Problems, Main Forms and Functions." Metareference across Media: Theory and Case Studies, edited by Werner Wolf. Rodopi, 2009, pp. 1-88. 